\title{
Effect of Screening Breast Cancer Nursing Intervention on Women Knowledge, Beliefs and Behavior Attendance to Health Center in Port Said City
}

Mai EL-Ghareap Hassan; Prof. Dr. Effat Mohamed El -Karmalawy; Prof.Dr. Hassan Ali Abdel Wahed; Dr. Hanan Hassan El-Ezaby

M.Sc. Family and community nursing, Faculty of Nursing, Port Said University; Professor of Community Health Nursing, Faculty of Nursing, Cairo University ;Professor of Family medicine, Faculty of medicine, Suez canal University; Lecturer of Family and community Health Nursing, Faculty of Nursing, Port-Said University

\begin{abstract}
Background: Breast cancer is the most common cancer and leading cause of death among women. Breast cancer screening plays an important role in early detection and decreasing mortality rate. Aim: The aim of this study was to evaluate effect of nursing intervention on women knowledge, attitudes, and behaviors regarding breast cancer screening in health care centers in Port Said city. Methods: A Convenience sample of 210 women who attended family planning clinics. This study was carried out in two primary health care centers. Data were collected through using three tools, first, structured interviewing questionnaire sheet, second health belief model scale; third tool was observational checklist for breast self-examination practice. Results: revealed that, there is statically significant improvement of women knowledge, attitudes and practice regarding breast cancer and its screening after the intervention, also there is statistically significant positive correlation between women's knowledge, attitude, practice of breast self-examination and education. Conclusion:. There was significant remarkable improvement in women knowledge, BSE practice and attitudes towards breast cancer and its screening after implementation of the educational program Recommendations: The study recommended that, breast cancer screening should be integrated in preventive health programs in primary health centers, mammography and ultrasound should be accessible and acceptable for attendance of primary health care services.
\end{abstract}

Key words: breast cancer, breast self-examination, knowledge, beliefs, screening behaviors. 


\section{INTRODUCTION}

Breast cancer is a major health problem throughout the world both in developed and developing countries (Christopher, 2010) Breast cancer is the most common type and the third most frequent cancer among women in the world, one in ten of all new cancers diagnosed each year is a cancer of female breast (Lim, 2007). Breast cancer refers to a malignant tumor that starts from cells of the breast, a malignant tumor is a group of cancer cells that may invade surrounding tissues or spread (metastasize) to distant areas of the body .Although breast cancer predominantly occurs in women it can also affect men (Stoppler, 2012).

In Egypt, similar to many other parts of the world, breast cancer is the most common cancer, it accounts for approximately $38 \%$ of the reported malignancies among Egyptian women (Denewer etal., 2010; Omaretal., 2010). Also it was reported that, according to the Gharbiah population-based cancer registry, that age standardized rate of 49.6 per 100,000 population(Elzawawy etal., 2008; Omar etal., 2010).

Causes of breast cancer aren't fully known although number of risk factors has been identified. The female sex is the most powerful risk factor. Women age considers risk factor to develop breast cancer which diagnosed less frequent among women in their thirties and younger; breast cancer is known to be more aggressive in the younger population as compared to older women. Also, race and ethnicity seems to play areole in breast cancer development (Christopher, 2010).

Early detection of breast cancer greatly increases the chances for successful treatment , through enhancing early diagnosis ,screening in addition recognizing signs of breast cancer and taking prompt action (Harmer, 2011) Therefore, promotion of awareness and early screening in the general female population may help to detect the disease at early stage as facilitate treatment (Forbes et al., 2011)The recommended screening methods for early detection of this fatal disease are: breast self-examination (BSE), clinical breast examination (CBE), ultrasound and mammography. Therefore, it is important that healthcare providers should inform women about the appropriate breast cancer screening methods (Oluwatosin, 2011).

The present study is conducted to shed light on importance of breast cancer screening and prevention by raising the women's awareness, self-protection abilities, improving the women's quality of life and enhancing over all understanding of breast cancer related knowledge, attitude and behavior.

\section{AIM OF STUDY:}

To evaluate effect of nursing intervention on women knowledge, beliefs, and behaviors regarding breast cancer screening in health care centers in Port Said city 


\section{SUBJECT AND METHODS:}

\section{Research design:}

A quasi- experimental research design was applied in this study to accomplish the aim of this study.

\section{Setting:}

This study was conducted in two primary health care centers in Port Said City namely Al-Kuwait health center (cover 30 thousands of population and serving 6 areas) and Omar Ben Elkatab health center (cover 40 thousands of population and serving 6 areas). The two selected primary health care centers has been chosen for higher flow rate of women attendance. Study was conducted at family planning clinic which provide family planning health services.

\section{Subjects:}

Women who attended family planning clinics in the two selected primary health care centers in Port Said city which mentioned before and who fulfilled the following inclusion criteria :

- All women attended family planning clinics aged 30 years and more.

- Women receiving hormonal contraceptives methods (injection, oral pills and subcutaneous capsules)

- Women hadn't previous history of breast cancer

\section{Sample Size:}

The sample size was calculated according to the following equation:-

$$
\mathbf{n}=\frac{2 \mathrm{pq}\left(\mathrm{z}_{\alpha / 2}+\mathrm{z}_{\beta}\right)^{2}}{-\left(\mathrm{p}_{1}-\mathrm{p}_{2}\right)^{2}}
$$

Accordingly, the estimated sample size was 190 women. After adjustment for a dropout rate of about $10 \%$, the sample size was 210 women. To detect the difference between the rate of satisfactory knowledge or positive attitude or adequate behavior before the intervention ( $\mathrm{p} 1=57 \%$ according to Guilford (2011) and after the intervention with expected $25 \%$ improvement with a $95 \%$ level of confidence ( $\alpha$ error $=5 \%)$, and a study power of $80 \%(\beta$ error $=20 \%)$ using the equation for the difference between two proportions (Schlesselman, 1982).

Purposive sample of 210 women who fulfilled the previous inclusion criteria starting with Al-Kuwait health center then Omar Ben Elkatab health center

\section{Tools for data collection:}

The researcher used four tools to collect the data as follow:

TOOL (I): The first tool was breast cancer screening knowledge structured questionnaire .It was used to assess women's knowledge about breast cancer and its screening practices. It was adapted from (McCance,etal. 1990). It was designed in Arabic form. Translation and back translation from English to Arabic was done for this tool .It mainly consists of three parts:

\section{First Part:}

- It includes sociodemographic characteristics of women such as age, level of education, address, occupation, residence, marital status, number of family member and family income.

\section{Second Part:}

- It includes women health history such as medical health history, reproductive and obstetric history, menstrual history, breast feeding history, contraceptive history, 
breast problem history and family heath history .The two parts were developed by researcher.

\section{Third Part:}

- It includes written questions to assess women's knowledge about breast cancer and breast cancer screening as following:-

- Breast cancer knowledge

This part consist of eight questions about breast cancer like early signs, symptoms, risk factors of breast cancer and its causes)

- Breast cancer screening

This part consist of nineteen questions about breast cancer screening Practices like age of beginning breast self-examination, frequency, timing, and its techniques. As well as knowledge about mammography, age of beginning and frequency.

\section{Scoring System:}

For the knowledge items, a correct response was scored 1 and the incorrect zero. For each area of knowledge, the scores of the items were summed-up and the total divided by the number of the items, giving a mean score for each part. These scores were converted into a percent score, means and standard deviations were computed. Knowledge was considered satisfactory if the percent score was $50 \%$ or more and unsatisfactory if less than $50 \%$.

TOOL (II):The second tool was champion's health belief model scale. It was used to assess women's health belief about breast cancer screening. It was adapted from (Champion, 1999). It consists of 58 items and comprised of eight-sub scale as follow:

A. Confidence: this construct include 11 items. It was used to assess perceived confidence in performing BSE.

B. Health motivation: this construct include 7 items. It was used to assess motivation of living a healthy life style.

C. Benefits of mammography: this construct include 5 items. It was used to assess benefit of having mammography.

D. Barriers to mammography: this construct include 11 items. It was used to assess barrier to have mammography.

E. Susceptibility: this construct include 5 items. It was used to assess perceived susceptibility to breast cancer.

F. Seriousness: this construct include 7 items. It was used to assess perceived seriousness of breast cancer.

G. Benefits of breast self-examination: this construct include 6 items . It was used to assess benefits of breast self-examination.

H. Barriers to breast self-examination: this construct include 6 items. It was used to assess barriers to breast self-examination.

It utilized 5-point Likert scale as follow (1) "strongly disagree", (2) "disagree", (3) "neutral, (4) "agree", and (5) "strongly agree.".

\section{Scoring System:}

For health beliefs, items were scored 5, 4, 3, 2, and 1 for the responses "strongly agree", "agree", "uncertain", "disagree", and "strongly disagree", respectively. The scores were reversed for negative statements. For each area, the scores of the items 
were summed-up and the total divided by the number of the items, giving a mean score for the part. These scores were converted into a percent score. The health beliefs was considered positive if the percent score was $60 \%$ or more and negative if less than $60 \%$.

TOOL (III): The third tool was observational checklist .It was adopted from (Salama,etal. 2013) to assess and evaluate women breast self-examination practice. It is divided into two positions in front of mirror (by demonstrating the steps on herself and using a doll) and in lying down position. The observational checklist includes fifteen items .The items were checked as "done", or "not done".

\section{Scoring System:}

In the observation checklists, the items "not done" and "done" were scored " 0 " and "1", respectively. For each procedure, the scores of the items were summed-up and the total divided by the number of the items, giving a mean score for the part. These scores were converted into a percent score, and means and standard deviations were computed. The practice was considered adequate if the percent score was $60 \%$ or more and inadequate if less than $60 \%$.

Tools were reviewed by a panel of five experts in the field of community health nursing and community medicine, to test its content validity. Modifications were done accordingly based on their judgment. Reliability was done by Cronbach's Alpha coefficient test, which revealed that each item of the utilized tools consisted relatively homogeneous items (Cronbach's Alpha $=0.855$ ). The necessary modifications were done.

\section{Fieldwork:}

\section{Phase (I): Pre-planning program}

Before starting up program design and planning, the researcher reviewed different relevant literature about breast cancer and screening practices.

\section{Phase (II): Program Planning}

A health education program was directed to women to improve their knowledge, attitude and practice about breast cancer \& breast cancer screening. Objectives of the program were settled, and educational program had include general knowledge of breast cancer as follow: definition of breast cancer, risk factor, sign and symptoms, types, prevention of breast cancer and different types of breast cancer screenings in accordance with the HBM including benefits ,barriers, confidence to practice of BSE , benefits ,barriers to mammography ,motivation ,susceptibility and seriousness. Booklet was developed by the researcher to be an educational aide throughout the program. The plan of the program was formulated as regard the number of sessions.

\section{Phase (III): Program Implementation}

After obtaining the official permission to conduct the study .The researcher meet and explain the aim of the study to women in a simple way, the consent of women were obtained before their participation in the study. The researcher attended family planning clinic for each primary health care center from 9:00 AM to 1:30 PM four days according to arrangement with women. Pre intervention, women's knowledge, attitude, worry scale and BSE practice tools were fulfilled before implementing the program. Women were divided in two groups each group consisted of approximately 8-10 women .The program was implemented for each group for three days, each day of the program contained two sessions each session took about one hour. The program was presented in clear, concise form and using different teaching methods such as lecture, demonstration and discussion. Data for the current study were collected through period from December 2013 to February 2015. 


\section{Phase (IV): Evaluation}

After program implementation, two post tests were done to evaluate the effect of the health education program on women's knowledge, attitude, and behavior regarding breast cancer screening; the first evaluation was done immediately by the end of the program implementation (post-test), the second evaluation done 3 months after program implementation (follow-up).

\section{RESULTS:}

Table (1): shows that nearly half $(45.7 \%)$ of women aged less than 35 years with a mean $36.3 \pm 5.5$ years. All women in the study were married .It was found that more than half $(53.8 \%)$ had intermediate education and the majority of them $(82.9 \%)$ were house wife. most of them $(92.9 \%)$ had sufficient income.

Figure (1): Indicates that in pre-test, most of women $(95.7 \%)$ had un satisfactory knowledge about $\mathrm{BC}$, meanwhile in post-test there was remarkable improvement in women total knowledge. all of them had satisfactory knowledge regarding breast cancer and its screening. The percentage of improvement had decline slightly in follow- up test to reach $98.6 \%$. Data also showed that there was statistically significant improvement in total area of knowledge in post-test and follow-up test compared with pre- test.

Table (2): Shows that in pre-test the minority of women (1.0\%) had positive health beliefs toward breast cancer and its screening. Meanwhile in post-test there is significant improvement in women total health beliefs most of them $(93.3 \%)$ had positive attitude. On the other extreme in follow- up test percentage of positive health beliefs toward breast cancer and its screening had declined to $40 \%$ of women. Data also showed that there was statistically significant improvement in women total health beliefs in post-test and follow-up test compared with pre- test $(\mathrm{p}<0.001)$.

Figure (2): Indicates that the minority of women (1.4\%) had adequate practice of BSE in pre-test. On the other extreme after the intervention there was significant improvement in total practice of BSE, all women had adequate practice in post-test; meanwhile $78.1 \%$ of women had adequate practice of BSE in follow- up test. Data also showed that there is statistically significant improvement in total BSE practice in post-test and follow-up test compared with pre- test $(\mathrm{p}<0.001)$.

Table (3): Shows that there is statistically significant positive correlation between women's knowledge, attitude, BSE practice and education. Also there is statistically significant positive correlation between women's attitude and menarche 
Table (1): Socio-demographic characteristics of women in the study sample $(n=210)$

\begin{tabular}{|l|l|l|}
\hline $\begin{array}{l}\text { Socio-demographic } \\
\text { characteristics }\end{array}$ & Frequency & Percent \\
\hline Age: & \multicolumn{2}{|l|}{} \\
<35 & 96 & 45.7 \\
$35-$ & 67 & 31.9 \\
$40+$ & 47 & 22.4 \\
\hline Range & $30.0-51.0$ \\
Mean \pm SD & $36.3 \pm 5.5$ \\
Median & 35.0 & \\
\hline Education: & & \\
None & 24 & 11.4 \\
Basic & 37 & 17.6 \\
Intermediate & 113 & 53.8 \\
University & 36 & 17.1 \\
\hline Marital status: & \multicolumn{2}{|l|}{} \\
Married & 210 & 100.0 \\
\hline Job status: & & \\
Housewife & 174 & 82.9 \\
Working & 36 & 17.1 \\
\hline Income: & \multicolumn{2}{|l}{} \\
Insufficient & 15 & 7.1 \\
Sufficient & 195 & 92.9 \\
\hline
\end{tabular}

Figure (1): Knowledge of breast cancer and its screening among women throughout the intervention

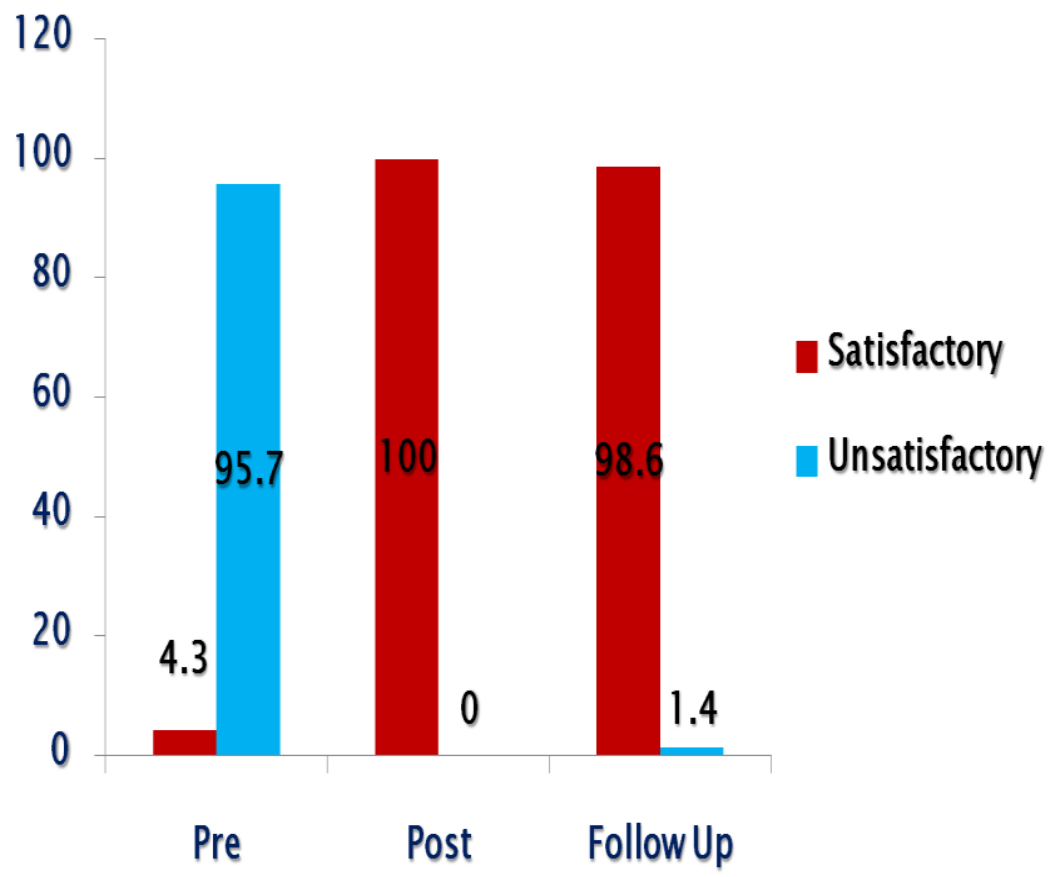


Table (2): health belifs towards breast cancer and its screening among women throughout the intervention

\begin{tabular}{|c|c|c|c|c|c|c|c|c|}
\hline \multirow{3}{*}{ Positive $(60 \%+)$ towards: } & \multicolumn{6}{|c|}{ Time } & \multirow{3}{*}{$\begin{array}{c}\mathbf{X}^{2} \\
\text { (p-value) } \\
\text { Pre-post }\end{array}$} & \multirow{3}{*}{$\begin{array}{c}\mathrm{X}^{2} \\
\text { (p-value) } \\
\text { Pre-FU }\end{array}$} \\
\hline & \multicolumn{2}{|c|}{$\begin{array}{c}\text { Pre } \\
(\mathbf{n}=\mathbf{2 1 0})\end{array}$} & \multicolumn{2}{|c|}{$\begin{array}{c}\text { Post } \\
(n=210)\end{array}$} & \multicolumn{2}{|c|}{$\begin{array}{c}\text { FU } \\
(n=210)\end{array}$} & & \\
\hline & No. & $\%$ & No. & $\%$ & No. & $\%$ & & \\
\hline Confidence & 37 & 17.6 & 209 & 99.5 & 203 & 96.7 & $\begin{array}{l}290.28 \\
(<0.001 *)\end{array}$ & $\begin{array}{l}267.91 \\
(<0.001 *)\end{array}$ \\
\hline Health motivation & 45 & 21.4 & 52 & 24.8 & 32 & 15.2 & $\begin{array}{l}0.66 \\
(0.42)\end{array}$ & $\begin{array}{l}2.69 \\
(0.10)\end{array}$ \\
\hline Benefits of mammography & 11 & 5.2 & 209 & 99.5 & 187 & 89.0 & $\begin{array}{l}374.22 \\
(<0.001 *)\end{array}$ & $\begin{array}{l}295.98 \\
(<0.001 *)\end{array}$ \\
\hline Barriers to mammography & 3 & 1.4 & 141 & 67.1 & 94 & 44.8 & $\begin{array}{l}201.25 \\
(<0.001 *)\end{array}$ & $\begin{array}{l}111.01 \\
(<0.001 *)\end{array}$ \\
\hline Susceptibility & 90 & 42.9 & 107 & 51.0 & 94 & 44.8 & $\begin{array}{l}2.76 \\
(0.10)\end{array}$ & $\begin{array}{l}0.15 \\
(0.69)\end{array}$ \\
\hline Severity & 37 & 17.6 & 45 & 21.4 & 19 & 9.0 & $\begin{array}{l}0.97 \\
(0.32)\end{array}$ & $\begin{array}{l}6.68 \\
(0.01 *)\end{array}$ \\
\hline Benefits of BSE & 46 & 21.9 & 209 & 99.5 & 168 & 80.0 & $\begin{array}{l}265.22 \\
(<0.001 *)\end{array}$ & $\begin{array}{l}141.80 \\
(<0.001 *)\end{array}$ \\
\hline Barriers to BSE & 20 & 9.5 & 129 & 61.4 & 27 & 12.9 & $\begin{array}{l}123.58 \\
(<0.001 *)\end{array}$ & $\begin{array}{l}1.17 \\
(0.28)\end{array}$ \\
\hline Total: & & & & & & & & \\
\hline & 2 & 1.0 & 196 & 93.3 & 84 & 40.0 & 359.61 & 98.32 \\
\hline Negative & 208 & 99.0 & 14 & 6.7 & 126 & 60.0 & $(<0.001 *)$ & $(<0.001 *)$ \\
\hline
\end{tabular}

(*) Statistically significant at $p<0.05$

Figure (2): Total practice of Breast Self-Examination (BSE) among women throughout the intervention

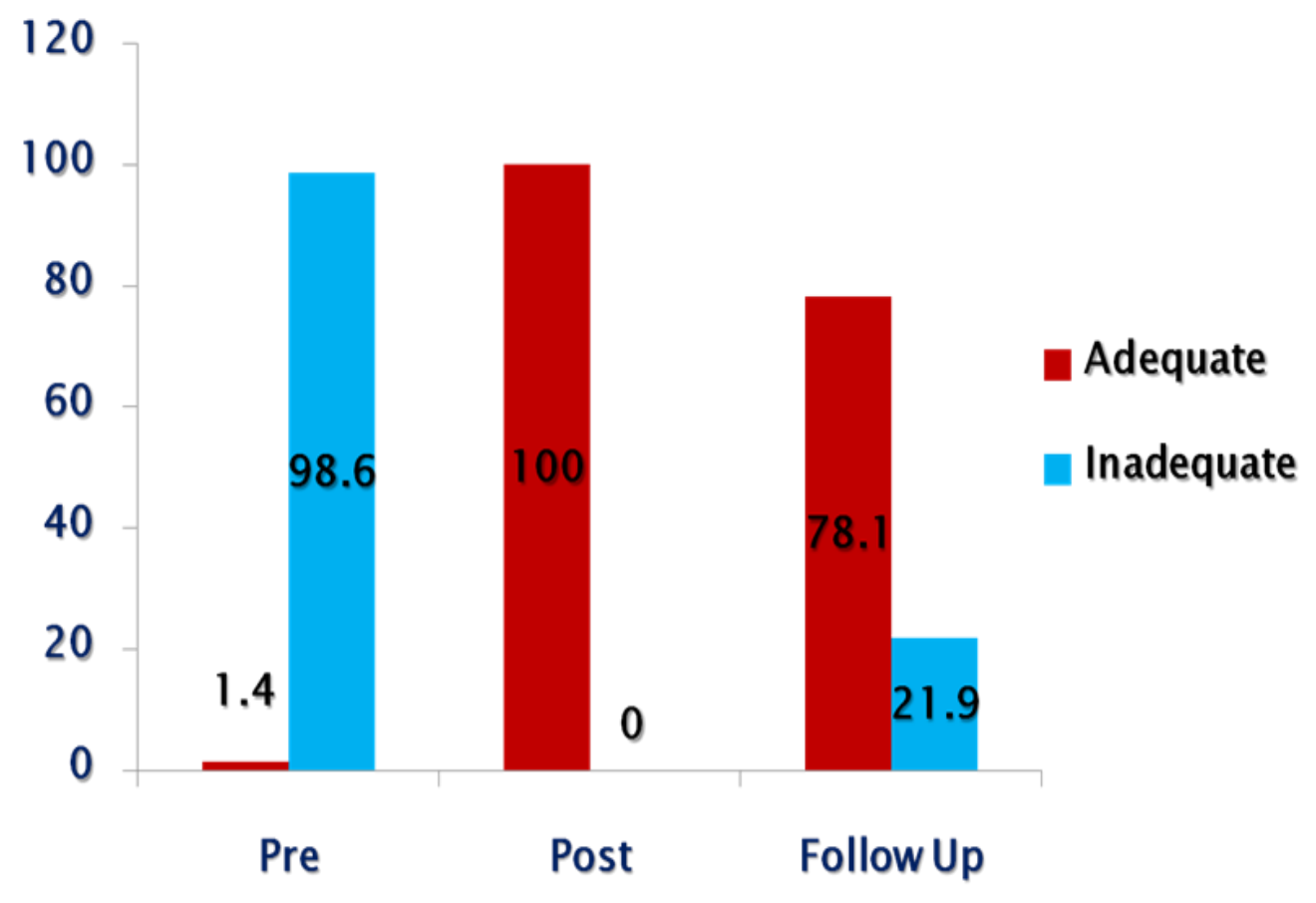


Table (3): Correlation between women's overall knowledge, attitude, and BSE practice scores and their personal characteristics

\begin{tabular}{|l|l|l|l|}
\hline \multirow{2}{*}{ personal characteristics } & \multicolumn{3}{|l|}{ Spearman's rank correlation coefficient } \\
\cline { 2 - 4 } & Knowledge & Attitude & BSE practice \\
\hline Age & -.030 & -.068 & -.011 \\
\hline Education & $.144^{* *}$ & $.084^{*}$ & $.088^{*}$ \\
\hline Menarche & .027 & $.080^{*}$ & .018 \\
\hline Reproductive age & .042 & .017 & .017 \\
\hline (*) Statistically significant at $\boldsymbol{p}<\mathbf{0 . 0 5}$ & \multicolumn{3}{|c|}{ (**) Statistically significant a $\mathbf{p}<\mathbf{0 . 0 1 t}$}
\end{tabular}

\section{DISCUSSION:}

Breast cancer in women is a major public health problem .It is considering the principal cause of death from cancer among women worldwide. (Feraly, etal. 2010). Early detection of breast cancer plays the leading role in saving women life, reducing mortality rates and improving the patient's prognosis (Komen, 2011). This study was carried out with the goal of filling a gap of important information about women knowledge, attitudes and behaviors regarding breast cancer screening in primary health centers. It was an attempt to answer questions of how much those women are knowledgeable of breast cancer and its screening, to what extent is their related practice adequate, and whether their knowledge ,attitude and behavior influenced by their socio demographic characteristics.

The study results revealed that most of women had unsatisfactory knowledge regarding breast cancer and its screening in the pre-test. This result is congruent with Salama, etal . (2013) who conducted peer education program on BC and BSE practice among Mansoura university female students and stated that $96.0 \%$ of participant had poor knowledge regarding BC ,also consistent with Seif\&Aziz, (2000) study that were conducted on working females at Ain shams university hospitals in Egypt most of those participant had un satisfactory knowledge about breast cancer .In the same line Royse \& dignan (2009) who conducted their study on 696 women in Kentucky in USA, they found that majority of participants had poor knowledge or limited knowledge about breast cancer and screening awareness.

After implementing the educational program the study result revealed that, there was clear remarkable improvement in total area of women knowledge in post-test. This result is congruent with Karayurto et al,(2009) who studied effect of peer and group education on knowledge ,beliefs and breast self-examination practice among university student in Turkey and found that knowledge score significantly increased after peer education. Also, this finding agrees with the results of the study carried out by Secginli \&Nahcivan (2011) who had reported improvement in breast cancer knowledge among Turkish women after the intervention program about breast cancer screening.

The study result also showed that there was statistically significant improvement in total area of knowledge in post-test and follow-up test compared with pre- test .this finding is consistent with the study conducted by Yousuf. (2010) among Saudi nursing students and found that participant's knowledge about breast cancer was 
statistically significant improved after program implementation in post- test compared with pre- test.

Health belief model has been used as theoretical frame work in this study to measure attitude related to breast cancer screening, As regard women's attitude about breast cancer and its screening the current study result showed that the minority of women had positive attitude toward breast cancer and its screening in pre-test. This may be due to unsatisfactory knowledge of women; knowledge could influence healthseeking behavior and change attitudes toward breast cancer. This findings agrees with EL Sharkawy etal,(2014) study that conducted on 98 women attending family planning clinics in Egypt and had reported that the majority of the women had negative beliefs about breast cancer and its screening pre guidelines implementation. Meanwhile the study results were in consistent with Baena, etal. (2014) who studied women's perceptions of breast cancer screening among 434 Spanish women and found that most of Spanish women $(99.1 \%)$ in his study had a positive attitude toward breast cancer screening.

The study results also showed that, there was statistically significant difference in health belief model subscales increased benefits and decreased barriers related to BSE in post-test and follow-up test . This may be due to the study program confirm on cognitive domain which increased women knowledge about breast cancer screening, correcting false belief regarding breast cancer screening and realizing importance of BC screening for breast health. This result was congruent with the study conducted by Torbaghan etal,( 2014) on 130 female employees of Zahedan University in Iran and reported that increased benefits and confidence related to breast self-examination and decreased perceived barriers significantly after intervention.

Also, agree with Aghamolaei,etal . (2011) who conducted an educational intervention based on health belief model on breast self-examination in Iran and reported that effectiveness of education program in promoting participant attitude grounded in the health belief model through increased perceived benefits and their perceived selfefficacy to perform this behavior and decreased perceived barrier to breast self-examination.

Furthermore, Farman,etal .(2014) who studied effect of education on preventive behaviors of breast cancer based on HBM which carried on 240 female in Zahedan city in Iran . They found that there was statistically significant difference in perceived susceptibility among women before and after education. On the other hand Lierman ,etal, (1994) studied effects of education and support on breast self-examination in older age women in USA and reported that there wasn't a significant change in the mean scores of perceived susceptibility and seriousness .

The results also showed that educational program had positive impact on women attitude through increased benefits and decreased barriers related to mammography in post-test and follow-up test. This result may be related to increased women knowledge about mammography screening, its technique, and benefit, correcting false belief regarding mammography and realizing importance of mammography for breast health.This result agree with Han et al. (2009) who conducted interventional study to improves breast cancer screening outcomes among 100 Korean-American women and found that breast cancer education programs influence women's health beliefs 
especially increased from pre- to post-test in perceived benefits and decreased perceived barriers to mammography.

Current study revealed that a significant remarkable improvement in practicing BSE in post-test and follow up test. This may be due to increased women knowledge, realized importance of BSE to maintain breast health, perceived its benefits as easily, readily and accessible method. This results goes in line with Abdelaziz,etal . (2009) who conducted their study among women in semi urban area in Alexandria, Egypt and reported that improved practice of BSE among the majority of women after implementing education program .Also, Salama, etal . (2013) who confirmed that Practice of BSE improved significantly after peer education.

The study results also portrayed that there was statistically significant positive correlation between women's attitude and education. This results consistent with findings of present study Harichi, etal . (2012), in their study indicated that illiterate or less educated people usually show poor health behaviors including cancer screening habits compared to better educated women and also stated that education effect not only attitude and knowledge, but also, on the degree of control individuals take about their own health .

\section{CONCLUSION:}

This study revealed that significant remarkable improvement in women knowledge, BSE practice and attitudes towards breast cancer and its screening after implementation of the educational program. There was statistically significant positive correlation between women's knowledge, attitude, BSE practice and education.

\section{RECOMMENDATIONS:}

- Data from this study re-enforce, the continuing need for more BC screening educational programs that are intended to attract the attention of women in reproductive age.

- Breast cancer and its screening should be integrated in preventive health programs in primary health care centers.

- Breast cancer screening services especially mammography and ultrasound should be accessible and acceptable for attendance of primary health care services.

\section{REFERENCES:}

Abd El Aziz H, Akl O, Ibrahim H, (2009): Impact of A Health Education Intervention Program about Breast Cancer among Women in a Semi-urban Area in Alexandria, Egypt. J Egypt Public Health Assoc.84 (1) 220-243

Aghamolaei T., Hasani L., Tavafian S. and ZareS. (2011): Improving Breast Self-Examination: an Educational Intervention Based on Health Belief Model, Iranian journal of Cancer Prevention; 4(2):82-87

Baena J., RosadoP., Expósito I., Gonzalez J. and Benítez J. (2014): Women's 
perceptions of breast cancer screening. Spanish screening programme survey, 23(6): 883-888

Bensley R. and Fisher J. (2009): Community health education methods: a practical guide. $3^{\text {rd }}$ ed. USA.Jones and Bartlett learning company

ChampionV.L. (1999). Revised susceptibility, benefits, and barriers scale for Mammography screening. Research in Nursing \& Health, 22, 341-348.

ChristopherI. (2010): Breast cancer epidemiology, $1^{\text {st }}$ ed.New York, Springer science,P. 343.

Denewer A., Hussein O. and Farouk O. (2010): Cost effectiveness of clinical breast assessment-based screening in rural Egypt. World J. Surg.; 34(9): 2204-2214

EL Sharkawy A, Hassan M, Abd El-Sattar R(2014):Effect of Nursing Educational Guidelines on Women's Awareness, Health Practices and Beliefs Regarding Prevention and Early Detection of Breast and Cervical Cancer .Life Science Journal;11(6) 707-724.

Elzawawy A.M., Elbahaiea A.M., Dawood S.M., ElbahaieH. and Badran A. (2008):Delay in Seeking Medical Advice and Late Presentation of Female Breast Cancer Patients in Most of the World. CouldWe Make Changes? The Experience of 23 Years inPort Said, Egypt, Breast Care journal 3(1):37-41

Farman K., Jalili Z., Zareban I. and Shahraki M. (2014):Effect of education on preventive behaviors of breast cancer in female teachers of guidance schools of Zahedan city based on health belief model ,J Education and Health Promotion. 3(77): 9531-13924

Ferlay J., Héry C., AutierP. and Sankaranarayanan R. (2010): Global Burden of Breast Cancer. Breast Cancer Epidemiol, 4(1) 1-19.

Forbes L., Linsell L. and AtkinsL. (2011): Promoting early presentation intervention increases breast cancer awareness in older women after 2 years: a randomized controlled trial. Br J Cancer, 105(1): 18-21.

Guilford K (2011): Breast cancer knowledge, beliefs and screening behaviors of college women, $\mathrm{PhD}$ university of Alabama

Han H.R., Lee H., Kim M.T. and KimK.B. (2009):Tailored lay health worker intervention improves breast cancer screening outcomes in no adherent KoreanAmerican women. Health Education Research J,24(2), 318-329

Harirchi I., Azary S., Montazeri A., Mousavi M., Sedighi Z., Keshtmand G., Zarinkolah Z. and KhalifehA. (2012): Literacy and Breast Cancer Prevention: a Population-Based Study from Iran, Asian Pacific Journal of Cancer Prevention, 13(8):3972-3930. 
Harmer V. (2011): Breast Cancer Nursing: Care and Management. $2^{\text {nd }}$ ed. Oxford. Wiley-Blackwell , .p 36

KarayurtO, Dicle A, Malak A (2009): Effect of peer and group education on knowledge beliefs and breast self-examination practice among University Students in Turkey. Turk J Med Sci, 39, 59-65.

Komen, S.G. (2011): Brest self-awareness. Availableat: ww5.komen.org/BSE

LermanC., Trock B., Rimer B.K., JepsonC., Brody D. and Boyce A. (1991):

Psychological side effects of breast cancer screening. Health Psychology, 10, 259267.

Lierman, L.M., Young, H.M., Powel-Cope, G., Georgiadou, F. and Benoliel, J.Q. (1994): Effects of education and support on breast self-examination in older women. Nurs Res, 43(3): 158-63.

Lim, E. (2007): Medicine surgery \& an integrated text book. 1st edition, Churchill Livingstone Elsevier, Philadelphia, p, 102.

McCance, K., Mooney, K., Smith, K. and Field, R. (1990): Validity and reliability of a breast cancer knowledge test. American Journal of Preventive Medicine, 6, 93-98.

Oluwatosin O. (2011): Primary Health Care Nurses Knowledge, Practice and Client Teaching of Early Detection Measures of Breast Cancer., BMC nursing journal 11( 22): $1472-6955$

Omar S.H., Rouesse J. and Khaled H. (2010):Breastcancer. $5^{\text {th }}$ ed. Cairo university press.9 (3):1-274.

Royse D. and Dignan M. (2009):Improving cancer knowledge and screening awareness: test of A telephone interviewer intervention. Journal of CancerEducation. 24(4): $315-318$

Salama H, Elsebai N, Abdelfatah F, Shoma A and Elshamy K(2013):

Effects of Peer Education on the Knowledge of Breast Cancer and Practice of Breast Self-Examination among Mansoura University Female Students Journal of American Science .9(10) 253-261

Schlesselman J. (1982). Case control studies: design, conduct, analysis. New York .Oxford Uni. Press, pp 145-146.

Secginli S. and Nahcivan N. (2006):Breast Self-Examination Remains an Important Component of Breast Health: A response to Tarrant. Int. J. Nurs. 43(4): 521-523.

Seif N.Y. and AzizM.A. (2000): Effect of breast self-examination training Programme on knowledge, attitude and practice of a group of working women. Journal of the Egyptian Nat. Cancer Inst.12(2):105-115. 
Stoppler, M. (2012): Breast cancer, retrieved on 10/12/2012available at http://www.medicinenet.com/breast_cancer/page4.htm

Tiwari S., Rathor C. and Singh Y. (2008): Health education, $1^{\text {st }}$ ed.New Delhi. APH publishing cooperation New Delhi; P. 13 - 14.

TorbaghanA.FaranfaraK, MoghaddamA,ZareiZ (2014): Improving Breast Cancer Preventive Behavior among Female Medical Staff: The Use of Educational Intervention based on Health Belief Model.Malays J Med Sci. 21(5): 44-50.

Yousuf S. (2010): Breast Cancer Awareness among Saudi Nursing Students, JKAU:Med. Sci.,; 17(3): p 67- 78 . 
تاثير تدخل تمريضى لفحوصات سرطان الثدى على معلومات ومعتقدات وسلوكيات السيدات

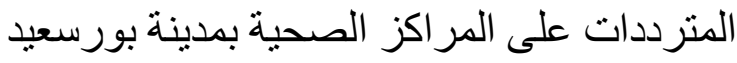

م.م/مى الغريب حسن أ ـد / عفت محمد القلرملاوى، أ.د/ حسن على عبد الو احد ، د/ حنان حسن العزبى

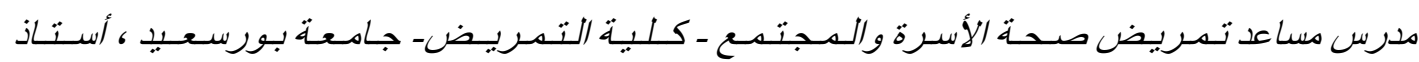

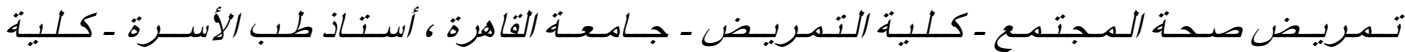

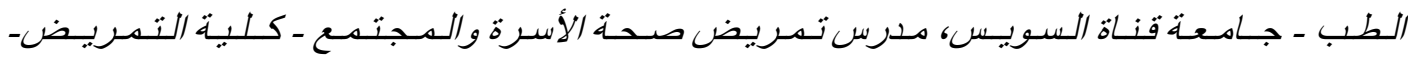
جامعسة بورسعبيد

\section{الـخـلاصـة}

سرطان الثذي هو الأكثر شيو عا والسبب الرئيسي للوفاة بين النساء وتلعب فحوصات سرطان الثدي دورا هاما في الكثف المبكر وخفض معدل الوفيات. الهدف من هذه الدر اسة تقييم أثر برنامج تثقيف صحى علي معلومات ،اتجاهات وسلوكيات فحص سرطان الثدى لدى السيدات المترددات على المر اكز الرعاية الصحية ببورسعيد. وقد أجريت هذه الدراسة في مركزين للرعاية الصحية الأولية (عمر بن الخطاب ومركز طبى الكويت) على عينة

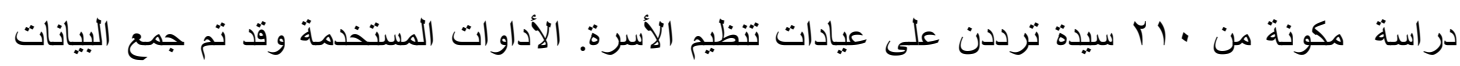
باستخدام r ادوات وهم استمارة لقياس المعلومات واستمارة لقياس الاتجاهات واخيرا استمارة ملاحظة لاداءالسيدات للفحص الذاتى للثدى ـ النتائج وقد اوضحت نتائج الدر اسة بعد تنفيذ البرنامج أن هناك تحسن كبير بشكل ملحوظ فى معلومات و اتجاهات وسلوكيات السيدات نحو سرطان الثذى وفحوصاته ، أيضا كان هنالك علاقة إيجابية ذات دلالة إحصائية بين المعرفة والاتجاهات و اداء السيدات للفحص الذاتي للثدي والتعليم . التوصيات وبناءا على نتائج هذه الدراسة أوصت الدراسة باستمرار الحاجة إلى المزيد من البرامج التنقيفية بسرطان الثدى و التي تهدف إلى جذب انتباه السيدات ، دمج فحوصات سرطان الثدى ضمن البرامج الوقائية في مر اكز الرعاية الصحة الأولية وإجر اء المزيد من الابحاث على المعتقدات الخاطئة للسيدات التي تعوق استخدام خدمات فحص سرطان الثدي

الكلمات المرشدة: سرطان الثذى ،فحوصات سرطان الثذى، الفحص الذاتى للثذى 